\title{
IMPLEMENTATION OF SCIENTIFIC APPROACH TO JURISPRUDENCE IN MADRASAH TSANAWIYAH NEGERI 2 MEDAN
}

\author{
Siti Nurzannah ${ }^{1}$ dan Rusydi Ananda ${ }^{2}$ \\ ${ }^{1}$ Teacherin MIN 3 Deli Serdang \\ 2Lecturer ini FITK UIN SU Medan
}

\begin{abstract}
The purpose of this study is: (1) To find out the design of learning that uses a scientific approach to learning Jurisprudence in MTs Negeri 2 Medan, 2) To find out the implementation of the scientific approach to learning Fiqh in MTs Negeri 2 Medan, 3) To find out the obstacles in implementing the scientific approach to Jurisprudence learning fiqih in MTs Negeri 2 Medan, 4) To find out the efforts to overcome it in the implementation of the scientific approach to Jurisprudence learning fiqih in MTs.Negeri 2 Medan, 5) To find out the views of Jurisprudence teachers on the implementation of the scientific approach to Jurisprudence learning fiqih in MTs.Negeri 2 Medan, 6) To find out the views of students on the implementation of the scientific approach to Jurisprudence learning fiqih in MTs.Negeri 2 Medan, 7) To find out the views of parents on the implementation of the scientific approach to learning Fiqh in MTs.Negeri 2 Medan. This research was carried out in Madrasah Tsanawiyah Negeri 2 Medan addressable in Jl. Peratun No. 3 Komplek Medan Estate. This type of research is qualitative research, Observation data collection techniques, Interviews, Field Notes, Documentation. The results of this study indicate that the design of the Scientific approach was carried out by the Jurisprudence teachers earlier before the beginning of the semester. In preparing the RPP the teacher also examines the syllabus and looks at KI and KD in the lesson plan. The implementation of the Scientific approach has been carried out by the Jurisprudence teacher quite well, but the implementation has not been maximized. Barriers to implementation of the Scientific approach include obstacles when drafting the RPP, and Implementation of 5M.
\end{abstract}

\section{Keywords: Scientific, Fiqih}

\section{INTRODUCTION}

The government requires the application of the 2013 curriculum, through a learning approach using a scientific approach or called a scientific approach. Scientific or scientific approach is considered a golden bridge for the development and development of integrated attitudes, skills 
and knowledge that are expected to produce productive, innovative and creative learners. As stated in Permendikbud No. 22 of 2016 concerning Basic and Secondary Education Process Standards.

Scientific approach is learning that adopts scientific steps in building knowledge through scientific methods. The learning process touches three areas, namely attitudes, knowledge, skills, and integrated knowledge. The teacher makes it easy for this process, by developing a learning atmosphere that gives students the opportunity to discover, apply their own ideas, become aware and consciously use their own strategies for learning. The teacher develops learning opportunities for students to pursue steps that bring students to a higher understanding, which was originally done with the help of the teacher but gradually became more independent. For students, learning must shift from "being told" to "actively seeking out" (Saefuddin, 2016: 42).

The results of the author's initial observations on the Implementation of the Scientific Approach in Jurisprudence in Madrasah Tsanawiyah Negeri 2 Medan. Found a problem that is interesting enough to be used as research material. Researchers see that Jurisprudence Teachers at MTs. Negeri 2 Medan has applied a scientific approach to learning, this is seen from the teacher implementing learning through the learning steps of the scientific approach through the $5 \mathrm{M}$ stages of observing, asking questions, gathering information, associating and communicating. Before starting the learning, Jurisprudence teachers have prepared the Learning Process Plan (RPP) and designed the learning media in such a way that is related to the material to be delivered, so that learning is more interesting, not monotonous and does not make students bored in participating in learning. But there are still obstacles encountered when applying a scientific approach is that the time is too short, students feel ashamed to ask questions, only a few students are active in learning activities and active students are the same people as class leaders, secretaries, and surgeons. Other students do not play an active role so that inhibits educators and students in the implementation of the learning process, especially on Jurisprudence subjects.

\section{THEORITICAL REVIEW}

The term scientific comes from English which is translated into scientific, which is scientific, scientific or based on science. Meanwhile, scientifically translated as "scientifically" or "scientifically". Based on this understanding, science has a scientific meaning and is carried out 
scientifically (Akhmadi, 2015: 15). While the approach according to the Big Indonesian Dictionary (2007: 246) is (1) the process, deeds, ways to approach; (2) efforts in the context of observational activities to establish relations with the person being investigated, methods for reaching an understanding of the research problem; design. From these two meanings, it can be interpreted that a scientific approach is an approach to something based on a particular scientific theory.

Alvert De Vito in Saefuddin and Berdiati (2015: 43) explains that scientific learning is learning that adopts scientific steps in building knowledge through scientific methods. The learning model needed is one that enables the cultivation of science thinking skills, the development of a "sense of inquiry" and the creative abilities of students.

The learning objectives with a scientific approach are based on the advantages of the approach. Some learning objectives with a scientific approach are: (1) to improve the ability of the intellect, especially the ability to think at a higher level of students, (2) to shape the ability of students to solve a problem systematically, (3) the creation of learning conditions where students feel that learning is a need, (4) high learning outcomes are obtained, (5) to train students in communicating ideas, especially in writing scientific articles, and (6) to develop student character (Kurniasih, 2014: 34).

\section{METHODS}

This research was conducted at Madrasah Tsanawiyah Negeri 2 Medan, located at J1. Peratun No. 3 Medan Estate Complex. MTs Negeri 2 Medan is a Madrasah Tsanawiyah Negeri that has implemented the 2013 Curriculum specifically in Jurisprudence. This research method is qualitative research, the presence of researchers acts as an instrument as well as data collectors. The presence of researchers is absolutely necessary, because besides that the presence of researchers is also a data collector. As one of the characteristics of qualitative research in data collection is carried out by the researcher himself. While the presence of researchers in this study as participant observers/participate, meaning that in the process of collecting data researchers make observations and listen as carefully as possible to the smallest though (Moleong, 2014: 137). The data source in this study can be divided into two, namely: (1) human, if the researcher uses a questionnaire or interview in collecting the data, the source of the data is called respondent, namely the person who responds or answers the researcher's questions, both written and oral questions. 
Human data sources function as subjects or key information is called (key informant). (2) not human, if the researcher uses observation techniques, the source of the data can be in the form of objects, movements or processes. the source of the data must be relevant to the focus of the study, such as: pictures, photographs, meeting notes or writings that are related to the focus of the study (Arikunto, 2006: 129). Data collection procedures: (1) Observation, (2) Interview is a conversation conducted by two parties, namely the interviewer (interviewer) who asks questions and interviewees (interviewees) who provide answers to these questions (Masganti, 2011: 188), and ( 3 ) documentation comes from the word document, which means the goods or events recorded. According to Sugiono (2009: 240).

\section{RESEARCH RESULTS AND DISCUSSION}

Learning design or often called RPP is something that is crucial in learning. The good learning process will greatly depend on the lesson plans that have been prepared before starting the learning. In making a good learning plan, the teacher must adjust the material, strategy / method, and the media used. Because every strategy cannot be applied to all material, so does the material that is suitable using a particular strategy / method.

Learning design is very important to do before starting learning, adjusting the material with the method, and class atmosphere is a basic thing that must be prepared by the teachers before starting learning. If not done, of course, will affect the smooth learning process. Moreover, learning using a scientific approach must be designed / prepared properly, so that when it is implemented in the classroom it can run smoothly. Mr. Syamsu, a Fiqh teacher in class VII and class IX January 30, 2019 said: The preparation certainly refers to the calendar, referring to Prota, Prosem. Other preparations, of course, exist, prepare material, then examine how much media will be used to support this material, determine that there is preparation but sometimes the shortage of teachers does not prepare lesson plans before teaching. So it is not as ideal as expected, sometimes the theory differs from the practice. When the teacher wants to come in tomorrow morning, the night should be prepared with all the plans, because of the demands of work, many tasks, as well as different social environments. So the RPP was prepared in advance and it has become ineffective.

The design / preparation should be adjusted to the material that is intended to be taught, but because of the large number of teacher 
assignments and demands that must be met makes most teachers make learning designs in advance, of course it will be less effective because learning designs made in advance there are differences with current material and conditions. Every design in Jurisprudence must be included in a Scientific approach with steps 5M. The scientific approach design is also not found in all teaching materials, but in certain materials such as discussion and practice materials. For Jurisprudence teachers who have long made learning plans and when implemented there are obstacles, the teacher also has a strategy to overcome them. So the teaching and learning process can run smoothly.

Implementation of Scientific approach in learning consists of three activities, namely preliminary activities, core activities, and closing activities. Implementation of the Scientific approach has its own characteristics in learning, the Scientific approach with its distinctive characteristics of observing, asking, reading, exploring, and communicating or abbreviated with $5 \mathrm{M}$ certainly has its own processes, strengths, weaknesses, and impacts in learning.

The results of observations made by researchers of teachers in MTs Negeri 2 Medan, especially Jurisprudence teachers, found that teachers in providing learning in classrooms have used a scientific approach as a method/strategy that is relevant to the current 2013 curriculum. Findings related to the implementation of the scientific approach in the study of Jurisprudence in MTs Negeri 2 Medan that researchers found were Observing, Asking, Collecting Information, Processing information / associating, and Communicating.

The following observations from researchers about the learning process of the scientific approach to the Jurisprudence subjects below: (1) preliminary activities. In this activity the teacher begins by greeting the students, then the teacher asks the class leader to lead the prayer, then the teacher tells students to read the Koran together in class. After finishing reading the Koran the teacher is absent students who are not present and convey the methods/ strategies and learning objectives. Then the teacher provides motivation for students to be active in learning. Then the teacher divides students into five groups, and instructs students to form their groups for five minutes each time and the teacher prepares the LCD Projector, (2) core activities. The results of the researchers' observations before the teacher starts the $5 \mathrm{M}$ steps of observing, asking, gathering information, exploring / processing information, and communicating. The teacher first provides the provisions in the discussion as each group is 
guided to give questions and may not ask questions about the questions in the book, and (3) closing activities. In this activity the teacher gives reinforcement to the material of Hajj and Umrah as well as information obtained by researchers. Next the teacher asks questions about things that are not understood by the students. Then the teacher gives a conclusion and closes the lesson with reading hamdalah.

The implementation of the scientific approach to the study of jurisprudence has been running quite smoothly, the teachers of jurisprudence often use the scientific approach in learning. For schools that implement the 2013 curriculum the use of science is no stranger, because the 5M strategy is suitable for use in learning. But this Scientific approach cannot also be used on all material but rather discussion material.

The obstacles of Jurisprudence teachers in MTs N 2 Medan using Scientific approaches are very small. Teaching experience of teachers who have been 25 years old, makes teachers able to control the learning process smoothly. The steps in the Scientific approach which are observing, questioning, exploring, associating, and communicating are not a problem for some Jurisprudence teachers in implementing Scientific. Each teacher has their own way of controlling the learning process in the classroom such as providing motivation at the beginning of learning.

In the process of teaching and learning every teacher certainly wants that learning can run smoothly. However, it does not rule out the possibility that obstacles in learning can occur at any time. Likewise, obstacles in the implementation of the scientific approach to fiqh learning in MTs N 2 Medan, the researchers got from four teachers include obstacles in the design, implementation, and assessment.

Overcoming obstacles from the implementation of the scientific approach to Jurisprudence in MTs N 2 Medan for Jurisprudence teachers has its own way of solving it. Even the Jurisprudence teachers who have experience in teaching have prepared / designed before the obstacles occur, so that obstacles are very small to occur. Ms. Minarni is one of the Jurisprudence teachers who experiences small obstacles such as many students who like to ask questions and corner friends who cannot answer. Ms. Minarni herself has a way of anticipating it by changing her group. Then when there are students who are not active in the discussion the teacher asks the group leader to note who is not active in the discussion, not only that the teacher also questions some students about the 
discussion of their friends and if they cannot answer then the student will receive punishment.

The viewassessment of Jurisprudence teachers on the implementation of the Scientific approach in Jurisprudence learning in MTs N 2 Medan was very good, the teachers were greatly helped by the Scientific approach in learning. Scientific Approach with its 5M characteristics (Observing, Asking, Exploring, Assuming, Communicating) is very effective in learning. However, the use of Scientific also cannot be on all material, let alone the material on Jurisprudence subjects which require each student to memorize verses and hadiths on the material.

Students 'views on the implementation of the Scientific approach to Jurisprudence learning at MTs N 2 Medan varied as they were interesting, exciting, fun / not bored, and increased students' courage in opinion. The following are the results of the researchers' interview with one of the students named Putri IX class who said: Learning with a scientific approach is interesting, not boring, especially when question and answer, so excited. More excited because of the discussion in the Scientific approach. Alhamdulillah, all our friends support us, play an active role. All are active even though all want to be the best.

Parents' views on the Implementation of Scientific Approach to Jurisprudence in MTs N 2 Medan are less felt. The parents know more about the use of the 2013 curriculum by the school. For parents the 2013 curriculum that was implemented was very good, because students could be more active in learning. In addition students are also more creative in making assignments such as learning media, and others.

\section{CONCLUSIONS}

Based on the results of the research described in the previous chapter, it can be concluded that: (1) Scientific approach designs are carried out by Jurisprudence teachers early before the beginning of the semester. In preparing the lesson plan the teacher also examines the syllabus and examines KI and KD in the lesson plan, not only that the teacher also examines the calendar, learning material, learning methods, assessment, time allocation, and learning resources, (2) the implementation of the scientific approach to fiqh learning conducted by four Jurisprudence teachers at MTs N 2 Medan is good enough. Scientific approach with its special characteristics of observing, asking, reading, exploring, and communicating is quite mastered by Jurisprudence 
teachers. Long teaching experience has made teachers accustomed to practicing the new 5M. Implementation of Scientific approach starts from the preliminary activities, core activities, closing activities. However, it is undeniable in the process when learning there are still some obstacles such as not in accordance with the allocation of time, especially the material whose arguments must be memorized, and the lack of tools such as uneven Infocus in each class, (3) obstacles in the implementation of the Scientific approach include obstacles when the design of lesson plans, and Implementation of $5 \mathrm{M}$. Obstacles to the Draft RPP made by the Jurisprudence teachers were prepared long before the beginning of the semester. This is because the teachers have demands from the school regarding the implementation of the 2013 Curriculum. Obstacles to the implementation of the scientific approach of the Jurisprudence are different such as cornering peers who cannot answer questions, some students are too active asking questions, some students are lazy in memorizing theories and propositions, students who ask questions are not change, the person is the same, there are materials that have the argument and the demands students must be able to memorize the argument, limited infocus, not all classes are available infocus, some students are active, and some students are not active, (4) efforts to overcome obstacles that occur in the implementation of the Scientific approach is to provide an opportunity for each student to prepare 1 question, give students about 10 minutes to memorize, if there are those who have not memorized, then they must memorize the next meeting, reproduce other media such as pictures, miniature material, and others. multiplying other media such as pictures, material miniature, etc., how to be persuaded, seduced, told to be lazy to be told, when persuaded directly to the person they are immediately motivated,(5) the view of Jurisprudence teachers in MTs N 2 Medan was very good, the teachers were greatly helped by the Scientific approach in learning. Scientific Approach with its $5 \mathrm{M}$ characteristics (Observing, Asking, Exploring, Assuming, Communicating) is very effective in learning. However, the use of Scientific also cannot be on all material, let alone material that requires each student to memorize verses and hadiths on the material. The advantage of the scientific approach is very suitable to be applied to materials that are practical and discussion, with this strategy the students can all be active and creative, (6) students' views on the use of the scientific approach to Jurisprudence varied, some say the learning is interesting, exciting, fun / not bored, and increase students' courage in opinion. This scientific approach is also able to adjust 
students 'learning styles such as audio, visual, and audio-visual learning styles, because in the learning process each learning style students will find learning situations according to their learning styles, (7) parents' views of scientific approaches in learning are less known by parents, this is due to the very rarely of parents seeing the teaching and learning process directly (from preliminary activities to closing activities), especially learning with a scientific approach. The parents know more about the use of the 2013 curriculum by the school. For parents of the 2013 curriculum which is implemented is very good, because students can be more active in learning. Parents know more about the use of the 2013 curriculum by the school. For parents the 2013 curriculum that was implemented was very good, because students could be more active in learning.

\section{RECOMMENDATIONS}

Recommendations that can be given are: (1) Schools should be more supportive of the learning tools and tools needed especially in the scientific approach. Schools must also constantly supervise and control the implementation of the 2013 Curriculum, especially the Scientific approach undertaken by teachers, and (2) for Teachers to always update their ability to teach, especially in the Scientific approach, so that learning can run effectively without any obstacles. Teachers must also be able to be creative / innovate towards Jurisprudence, given the rapid development of the modern era that is happening. So the teacher must be able to compensate and follow these developments, so students can be directed in a positive direction.

\section{REFRENCES}

Akhmadi, Agus, (2015) Pendekatan Saintifik Model Pembelajaran Masa Depan, Yogyakarta: Araska.

Arikunto, Suharsimi, (2006) Prosedur Suatu Pendekatan praktik. Jakarta : Rineka Cipta.

Hosnan, M, (2014) Pendekatan Saintifik dan Kontekstual dalam Pembelajaran Abad 21. Bogor, Ghalia Indonesia.

Kurniasih, Imas, (2014) Sukses mengimplementasikan Kurikulum 2013. Jakarta:kata Pena..

Mardianto, (2013) Psikologi Pendidikan Landasan Untuk Pengembangan Strategi Pembelajaran. Medan: Perdana Pablishing. 
Masganti, (2011) Metodologi Penelitian Pendidikan Islam, Medan: IAIN Press.

Moleong, Lexy J, (2014) Metodologi Penelitian Kualitatif. Edisi Revisi. Cetakan ketigapuluhdua. Bandung: Remaja Rosdakarya Offset.

Mulyasa, (2013) Pengembangan dan Implementasi Kurikulum 2013. Bandung: Remaja Rosdakarya.

Nasih Ahmad Munjih dan Khalida Lilik Nur, (2009) Metode dan Tehnik Pembelajaran Pendidikan Agama Islam. Bandung: Refika Aditama.

Nurdin, Syafaruddin, (2002) Guru profesional dan Implementasi Kurikulum. Jakarta: Penerbit Ciputat Pers.

Rusydi Ananda. (2019) Perencanaan Pembelajaran. Medan: LPPPI.

Saefuddin, Asis, (2014) Pembelajaran Efektif. Bandung: Remaja Rosdakarya.

Sugiyono, (2010) Metode Penelitian Pendidikan (Pendekatan Kuantitatif, Kualitatif, $R \in \mathcal{E})$ ). Bandung: Alfabeta. 